Rachel Cahill-O'Callaghan

\title{
Beneath Politics: Values Based Judicial Appointment
}

This paper draws on theories from psychology to argue that political ideology is a poor indicator of judicial decisions. Values play an important role in decision making and this paper argues that a value-based appointments process may enhance diversity and provide a more accurate reflection of judicial decision making.

Category of articles: Science

Citation: Rachel Cahill-O'Callaghan, Beneath Politics: Values Based Judicial Appointment, in: «Justice - Justiz - Giustizia» 2021/1 


\section{Contents}

1. Introduction

2. The limits of the influence of political position on decision-making

3. The psychology of decision-making

4. A brief introduction to personal values

5. The factors that influence judicial decision-making reflect values

6. Appointments and values

\section{Summary}

[1] At the heart of the Swiss Supreme Court appointments process is the recognition that robust and legitimate judicial decision-making is underpinned by a bench which reflects a diversity of views. Unlike many common law countries, the process of appointment also overtly acknowledges that extra-legal factors may play an important role in judicial decision-making and influence the final outcome of legal cases. By overtly acknowledging and appointing based on political affiliation the process seeks to achieve this necessary diversity of views through democratic representation. Although many studies in the U.S. have demonstrated the association between political affiliation and judicial decisions in the Supreme Court, there is increasing recognition that political ideology is a poor proxy for the many conscious and less conscious factors that influence the final outcome.

[2] Drawing on theories from psychology on personal values, this paper will argue that judicial appointments grounded in political allegiance alone may serve to undermine the principles of diversity and democratic representation the appointments process seeks to achieve. Psychological studies of decision-making highlight the many and complex processes that influence the final outcome. These processes are enhanced where the outcome is not easily determined, the nature of the cases heard by the Supreme Court. In a proportion of these cases, the decision may not only rely on the legal principles but also on the characteristics of the judge who makes that decision.

[3] Political ideology is only one of the many characteristics that have been implicated in the legal literature. Many other facets of the individual judge's personality have been demonstrated to play a role in the final decision, not least how the judge views their role on the bench (activist or restraintist) and the judicial processes of reasoning (outcome orientated or law orientated). Psychology directs us to a range of other factors that influence the final outcome including the role of heuristics, those instinctive responses which frame our decision-making processes. These studies highlight that the final decision is not a facet of any individual factor but the complex outcome of many factors and processes. An appointments process which promotes one characteristic above another, masks this complexity.

[4] Personal values are central to individual identity. They are the lens through which we see the world and frame the decisions we reach. Political ideology is one manifestation of an individual's values, but the influence of values extends beyond political ideology. Personal values underpin many of the facets of the judicial character which influence decision-making. But again, they extend beyond these conscious positions, values function at every level of decision-making, from the initial intuitive response to the deliberative reasoning and the final outcome. The innate nature of our values means that values serve as an influence in all decision-making.

[5] Judges are not immune from these innate influences. In cases where the law does not dictate an answer or where there is an element of weighing up different aspects under consideration, 
personal values play a role. In reaching a decision, in cases which divide judicial opinion, the judge will prioritise certain value(s). This is evident in the UK Supreme Court, where in the most difficult cases, judges will reach decisions consistent with their value priorities. Values offer a richer and deeper insight into the facets of the judicial character that influence legal decisions.

[6] Although many do not express a political allegiance, we all have value priorities. An appointment process that asserts democratic representation should not be limited to the value manifestation of political ideology, rather it should reflect the many value priorities affirmed by the population. Unlike political party allegiance, values are central to our identity and can be easily ascertained through psychometric testing. A values-based appointments process would offer a more nuanced and balanced representation of the demos. It would enhance diversity, widen the pool for selection and offer opportunity to those excellent judicial candidates who are not eligible to participate through the current political party orientated process. Indeed, the prioritisation of values rather than ideology would limit concerns about the party political influence at the heart of the ballot debate. The benefits of a value-based appointment system could be further enhanced with a more fundamental change of the appointments process.

[7] The use of single priority indicators limits the potential diversity that difference brings. The appointments process as it stands uses the narrow criteria of political ideology as a tool of exclusion, limiting the pool to those who share a political viewpoint. Although, values are more inclusive, the appointments commission will have to decide which value profiles it seeks to amplify in the selection process and in doing so may exclude excellent candidates and limit diversity. [8] Rather than using selection criteria to exclude applications, value diversity should be used to support inclusion. Our values reflect our life experiences. Value diversity on the bench and the benefits this would bring is a reflection of a multitude of life experiences. Value assessment and diversity could be used to support inclusion and to encourage a wider pool of candidates with a range of life experiences into the selection process. Thus the value-based appointments process recognises the complexity of humanity and the many factors that influence the judicial decision. An appointments process that promotes diversity will ensure that a range of value priorities are reflected in the Swiss Supreme Court. A values-based appointments system will create a court that reflects the many facets of diversity of the demos it serves.

\section{Introduction}

[9] The discussions surrounding the appointments criteria to the Swiss Supreme Court and the contemplation of the "lottery» system highlights the debates surrounding the characteristics of the judge which should determine appointment. At the heart of these debates is the desire to seek a legitimate foundation for the decisions that judges reach. Decisions which impact on the lives of individual citizens, and in the case of the final courts of appeal the repercussions of a decision may reverberate through society.

[10] In Switzerland, this legitimacy is founded on a diverse representation on the bench. The appointments process recognises that robust, unbiased decision-making requires a diversity of views and that although law and legal principles are central to every legal decision, in hard deci- 
sions where the law is uncertain, extra-legal factors play a role. ${ }^{1}$ In the current process, it is suggested that this can be satisfied by an appointments process which prioritises political allegiance. Although the process affirms diversity and that differences of view enhance decision-making, a process based on political affiliation alone suggests that the only extra-legal factor that influences judicial decision-making is political ideology and political positioning. This narrow view of judicial decision-making neglects the many characteristics of an individual judge that have been implicated in the final decision.

[11] A judicial decision is a constrained choice between alternatives. A decision constrained by legitimate legal factors, institutional and procedural norms, and structures associated with the role of the judge. ${ }^{2}$ But even within these constraints, there is increasing recognition that in a case where a judge exercises discretion, the judicial decision is subject to a range of extra-legal conscious and subconscious influences. Many of these factors are underpinned by personal values. Personal values are a central facet of our identity and serve as both conscious and less conscious influences on our decision-making. Values are reflected in political ideology but also extend beyond ideology.

[12] This paper will draw on theories from psychology and data from a study of the UK Supreme Court to argue that personal values offer a more nuanced and richer insight into judicial decisionmaking than political ideology. I will argue that an appointments process which selects value priorities will enhance diversity and overcome many of the perceived limitations of the current system. However, even a system which used values to select a pool of potential candidates must devise criteria to identify the characteristics it wishes to include and amplify.

[13] The debates on the reform of the Supreme Court appointments process offer an opportunity for a more fundamental change. In contrast to the current selection process, which limits the selection pool based on individual characteristics, value assessment and enhancing value diversity should be used to support inclusion. Our values are formed by our life experiences. A valuesbased system of appointment would not limit the selection pool based on value priorities rather it would recognise the importance of diversity beyond the traditional demographic identifiers of nationality, gender, ethnicity, political ideology and include many other factors that influence our values such as class, legal and life experience. A values-based appointments system should be used to encourage a wider pool of candidates with a of range life experiences into the selection process, to embrace the complexity of humanity and the many factors that influence the judicial decision. A values-based system of appointment would encourage the widest range of value priorities and through this would ensure the democratic representation the Swiss Supreme Court appointments system seeks to achieve.

Cass Sunstein, Why Societies need Dissent. Vol. 9. Harvard University Press, 2005.

2 See for example Michael A. Bailey and Forrest Maltzman, The Constrained Court: Law, Politics, and the Decisions Justices Make. Princeton University Press, 2011.), 


\section{The limits of the influence of political position on decision-making}

[14] The political nature of the appointments process in the U.S. has underpinned extensive study of the influence of political ideology on decision-making in the Supreme Court. ${ }^{3}$ These studies are the basis for the attitudinal model of judicial decision-making and the proponents of this model argue that Supreme Court Justices exercise judicial discretion to give effect to an individual Justice's policy preference. Policy decisions are thus the dominant consideration in the exercise of judicial discretion. ${ }^{4}$ This absolutist model of political judicial decision-making which centres on political ideology alone is highly contested. Political preferences may play an important role in some cases, but this influence is constrained and moderated by other factors. ${ }^{5}$ Indeed, several conscious extra-legal factors have been demonstrated to moderate the influence of political ideology on decision-making. One such moderator is strategy.

[15] The strategic model of decision-making suggests that judges do not make decisions in isolation, but rather consider the potential actions of other actors and modify their decision accordingly. In contrast to the attitudinal model, the strategic model recognises in the context of a decision made by a panel, that the final outcome is a reflection of the interdependent nature of the decision-making process rather than a single individual. ${ }^{6}$ Each judge who is on the panel may make a strategic choice to sacrifice political preferences for a range of reasons, not least their concern for legal clarity. ${ }^{7}$ Indeed, Baum suggests «if judges conceive a good law as encompassing coherent legal rules, then judges on an appellate court may compromise with each other to achieve clear consensual decisions.» ${ }^{8}$

[16] The moderation of the influence of political ideology is not simply limited by compromise. How the individual judge views their role and function in interpreting and evolving the law un-

3 For example, Glendon A. Schubert, The Judicial Mind Revisited: Psychometric Analysis of Supreme Court Ideology Oxford University Press 1974; Jeffrey A. Segal/Lee Epstein/Charles M. Cameron/Harold J. Spaeth, Ideological Values and the Votes of US Supreme Court Justices Revisited, The Journal of Politics, 1995, 57, 3, 812823; Paul Brace/Laura Langer/Melinda Gann Hall, Measuring the Preferences of State Supreme Court Judges, The Journal of Politics, 2000, 62, 2, 387-413; Jeffrey A. Segal and Harold J. Spaeth, The Supreme Court and the Attitudinal Model Revisited. Cambridge University Press, 2002, Lee Epstein/Andrew D. Martin/Jeffrey A. Segal/Chad Westerland, The Judicial Common Space, The Journal of Law, Economics, and Organization, 2007, 23, 2, 303-325; David S. LAw and David ZARING, Law Versus Ideology: The Supreme Court and the Use of Legislative History, William. \& Mary Law. Review 2009, 51, 1653.

4 Whilst this influence is important, it must be noted that the influence is not fixed and studies by EPSTEIN, MarTiN, QuinN \& Segal (2007) demonstrated individual ideological change over time. Lee Epstein/Andrew D. Martin/ Kevin M. Quinn/Jeffrey A. Segal, Ideological Drift among Supreme Court Justices: Who, When, and How Important, Northwestern University Law Review 2007, 101,1483.

5 See for example Bailey and Maltzman (2011) FN 2.

6 Lee Epstein and Jack Knight, Toward a Strategic Revolution in Judicial Politics: A look back, a look ahead, Political Research Quarterly, 2000, 53, 3, 625-661, William N. Eskridge JR, Overriding Supreme Court Statutory Interpretation Decisions, Yale Law Journal, 1991, 331-455; David E. KLeIN and Robert J. Hume, Fear of Reversal as an Explanation of Lower Court Compliance, Law \& Society Review 2003, 37, 3, 579-581.; Virginia A. Hettinger/ Stefanie A. Lindquist/Wendy L. Martinek, Comparing Attitudinal and Strategic Accounts of Dissenting Behaviour on the U.S. Courts of Appeals, American Journal of Political Science, 2004, 48, 1, 123-137.

7 Thomas J. Miceli and Metin M. Cogel, Reputation and Judicial Decision-Making, Journal of Economic Behavior \& Organization, 1994, 23, 1, 31-51; HARry T. Edwards, The Effects of Collegiality on Judicial decision-making, University of Pennsylvania Law Review, 2003, 155, 5, 1639-1690; Virginia A. Hettinger/Stefanie A. Lindquist/ Wendy L. MartineK, Judging on a Collegial Court: Influences on Federal Appellate decision-making. University of Virginia Press, 2007.

8 LAWrence BAUm was citing work by Harry T. EDwards, «The effects of Collegiality on Judicial decision-making» University of Pennsylvania Law Review 2003, 1 151, 1639 - 1689. Lawrence Baum, Motivation and Judicial Behaviour: Expanding the Scope of Inquiry, in: David E. Klein and Gregory E. Mitchell (eds.), The Psychology of Judicial decision-making, Oxford University Press, 2010. 
derpins another conscious factor which moderates the influence of ideology: role orientation. Role orientation is typically viewed in a legal context as an element of the judicial personality which encourages a conscious positioning of the legal decision. This categorisation opposes «activist» with «non-activist or restraintist» orientation. Activism is identified as the subordination of precedents, statutes in deference to the judge's personal attitudes, policies, values and goals. ${ }^{9}$ In contrast, a «restraintist» judge strictly follows precedents with deference to the constitution and legislative intent. ${ }^{10}$ Although there has been a tendency to equate judicial activism with political ideology, linking «activism» with liberal ideology and «restraintism» with conservative ideology, Sunstein, Schkade, Ellman, \& Sawicki (2007) demonstrated that there is no direct connection but rather that judicial role orientation may serve to mediate a specific policy position. ${ }^{11}$

[17] These studies suggest that who the judge is, how they perceive the role of law, and their approach to reasoning, all moderate the relationship between political ideology and judicial decisions. The current appointment process, which assumes that ideology is consistently accurately reflected in judicial decisions, fails to account for these more complex conscious considerations in human decision-making. ${ }^{12}$ But there is a more fundamental flaw. Underpinning the political model of appointment is the assumption that judicial decision-making is under strict conscious control, overt, rational, uniform, consistent and easily measurable. But this narrow view of human decision-making is undermined by the detailed psychological understanding of multiple systems and less conscious processes that underpin human decision-making.

\section{The psychology of decision-making}

[18] In recent years there has been extensive research into the influence of psychological processes that underpin decision-making which highlights the limits of conscious control and the importance of subconscious mental processes. The internal processes and influences that drive decisions in an undetermined choice situation, where the outcome is not clearly dictated, provides important insight into the potential role of subconscious factors in judicial decision-making. Indeed, the seminal paper by Guthrie, Rachlinski and Wistrich demonstrated the many subconscious processes that influence a judicial decision. ${ }^{13}$

[19] The influence of these factors is mediated at various levels of analysis and cognition ranging from automatic and intuitive mental processes to detailed conscious logical reasoning. The work of Amos Tversky and Nobel prize winning Daniel Kahneman categorised these mental processes

9 For an excellent review see JAmEs L. Gibson, «From Simplicity to Complexity: The Development of a Theory in the Study of Judicial Behaviour», Political Behaviour 1983, 5, 7.

10 James L. Gibson, Role Orientations, Attitudes and Decisions: An Interactive Model, The American Journal of Political Science 1978, 71, 911; JAmes J. Gibson, The Role Concept of Judicial Research, Law and Policy Quarterly 1981, 3, 291.

11 Cass Sunstein/David Schkade/Lisa M. Ellman/Andres Sawicki, Are Judges Political? An Empirical Analysis of the Federal Judiciary. Brookings Institution Press, 2007.

12 For discussion of the legal constraints on judicial decision-making see Bailey and Maltzman (2011), FN 2.

13 Chris Guthrie/Jeffrey J. Rachlinski/ Andrew J. Wistrich, Inside the judicial mind, Cornell Law Review 2000, 86, 777; ANdrew J. Wistrich/Chris Guthrie/Jeffrey J. Rachlinski, Can Judges Ignore Inadmissible Information-the Difficulty of Deliberately Disregarding. University of Pennsylvania Law Review, 2004, 153, p.1251; Chris Guthrie/ JefFrey J. Rachlinski/ Andrew J. Wistrich, «Blinking on the Bench: How Judges Decide Cases.» Cornell Law Review $2007,93,1$. 
into two forms. ${ }^{14}$ System 1 thinking is the first phase, intuitive, rapid and subconscious. It is here that heuristics, our instinctive responses, are initiated. System 2 decision-making is a deliberate, effortful and slow process. It is rule based reasoning often described as «logic» which relies on articulated reasons and evidence. It could be argued that judicial decision-making is system 2 thinking and the subconscious intrinsic elements of the decision-making, characterised by system 1 thinking, have no role to play. However, this is the law of books, in indeterminate cases the reality of decision-making is more complex. KaHNeman and Frederick posit that all decision makers initially make intuitive judgements (system 1) on what is «right» and «fair» which they might or might not over-ride with deliberation (system 2). ${ }^{15}$ This instinctive response of what is «right» and «fair» is influenced by extra-legal factors both external and internal including personal experiences and values. Guthrie, Rachlinski \& Wistrich (2007:141) suggest that these influences are mediated through the psychological processes of judicial decision-making:

\begin{abstract}
«[J]udges attempt to reach their decisions utilising facts, evidence and highly constrained legal criteria, while putting aside their personal biases, attitudes, emotions, and other individuating factors. Despite their best efforts, however, judges like everyone else, have two cognitive systems for making judgments - the intuitive and the deliberative and the intuitive system appears to have a powerful effect on judicial decision-making.» ${ }^{16}$
\end{abstract}

[20] This influence of these facets of personality, including values, is heightened where legal rules and principles do not provide a clear answer and the decision requires the exercise of judicial discretion. These are often the nature of matters heard by the Supreme Court.

\title{
4. A brief introduction to personal values
}

[21] Values and value judgments are used in legal literature to cover a variety of concepts. Within the context of legal judgments, the term «values» has been used to cover a range of concepts and has been used synonymously with moral obligations. Although morals are derived from values, the two are not the same. Morals are concerned with the «rightness or wrongness» of a specific action. In contrast, values are «enduring beliefs that a specific mode of conduct is personally or socially preferable to an opposite or converse mode of conduct or end state of existence». ${ }^{17}$

14 Daniel Kahneman/Paul Slovic/Amos Tversky (eds.), Judgment under Uncertainty: Heuristics and Biases. Cambridge University Press, 1982; Thomas Gilovich/Dale Griffin/Daniel Kahneman (eds.), Heuristics and Biases: The Psychology of Intuitive Judgment. Cambridge University Press, 2002; Daniel Kahneman and Amos Tversky, Choices, Values, and Frames, Handbook of the Fundamentals of Financial decision-making: Part I, 2013, 269-278.

Daniel Kahneman and Shane Frederick, Representativeness Revisited: Attribute Substitution in Intuitive Judgment, in: Thomas Gilovich/Dale W. Griffin/Daniel Kahneman (eds.), Heuristics and Biases: The Psychology of Intuitive Judgment, Cambridge University Press 2002.

16 Chris Guthrie/Jeffrey J. Rachlinski/Andrew J. Wistrich, Blinking on the Bench: How Judges Decide Cases, Cornell Law Review 2007, 93, 1.

17 Mitton RoкeAch, The Nature of Human Values, Free press, 1973, page 5. 
[22] Values act as guides for the evaluation of the social world. ${ }^{18}$ We appraise objects, actions, situations and people in relation to our values, and do so with very little cognitive effort. ${ }^{19}$ As such, values frame our decision-making. Shalom Schwartz developed a model of values which has been used in many psychological studies ${ }^{20}$ including studies to identify the relationship between values and communist rule ${ }^{21}$, emigration ${ }^{22}$ and environmental attitudes. ${ }^{23}$ The model has also been used in a wide range of behavioural studies ${ }^{24}$ demonstrating a relationship between values and individual views including political ideology ${ }^{25}$ and pro-social behaviour. ${ }^{26}$

[23] The model of values developed by Schwartz positions universally held values into ten overarching motivations. ${ }^{27}$ These motivations are driven by three universal requirements, the needs of individuals as biological organisms, the requirements of co-ordinated social interaction and, finally, the requirements for the smooth functioning and survival of groups. ${ }^{28}$ The ten motivational goals, which encompass the values, are self-direction, stimulation, hedonism, achievement, power, security, conformity, tradition, benevolence and universalism..$^{29}$ Each value is defined by its motivation, for example self-direction has the motivational objective of independent thought and action. Those who seek self-direction enjoy being outside the control of others. In contrast, tradition has the motivational goal of respect, commitment and acceptance of the customs and ideas that one's culture or religion impose on an individual. Those who value tradition place cultural customs and ideals above personal interests.

18 Phillip E. Tetrock, «A Value Pluralism Model of Ideological Reasoning» Journal of Personality and Social Psychology 1986, 50, 819.

19 Norman T. Feather, «Values, Valences and Choice: The Influence of Values on the Perceived Attractiveness and Choice Alternatives.» (1995) 68 Journal of Personality and Social Psychology 1135; Anat Bardi and Shalom H. SchwarTz, Values and Behaviour: Strength and Structure of Relations, Personality and Social Psychology Bulletin 29, 2003, 1207.

20 For examples of these studies see Gregory R. Maio and James M. Olson, «Values as Truisms: Evidence and Implications» Journal of Personality and Social Psychology 1998, 74, 294; Mark M. Bernard/Gregory R. Maio/ James M. Olson, «The Vulnerability of Values to Attack: Inoculation of Values and Value-Relevant Attitudes» Personality and Social Psychology Bulletin 2003, 29 63; Gregory R. Maio And Others, «Changing, Priming, and Acting on Values: Effects via Motivational Relations in a Circular Model», Journal of Personality and Social Psychology, 2009, 97, 699 .

21 Anat Bardi and Shalom H. Schwartz, «Relations among Sociopolitical Values in Eastern Europe: Effects of the Communist Experience?» Political Psychology, 1996, 525; Shalom H. Schwartz and Anat Bardi, «Influences of Adaptation to Communist Rule on Value Priorities in Eastern Europe» Political Psychology, 1997, 18, 385.

Eugene Tartakovsky and Shalom H. Schwartz, Motivation for Emigration, Values, Wellbeing, and Identification among Young Russian Jews, International Journal of Psychology, 2001, 36, 88.

23 Wesley P. Schultz and Lynette Zelezny, Values as Predictors of Environmental Attitudes: Evidence for Consistency across 14 Countries, Journal of Environmental Psychology, 1999, 19, 255.

24 Gregory R. Maio And Others, Addressing Discrepancies between Values and Behavior: The Motivating Effect of Reasons, Journal of Experimental Social Psychology, 2001, 37, 101; Thierry Devos/Dario Spini/Shalom H. Schwartz, Conflicts among Human Values and Trust in Institutions, British Journal of Social Psychology, 2002, $41,481$.

25 Gian Vittorio Caprara And Others, «Personality and Politics: Values, Traits, and Political Choice» Political Psychology, 2006, 27, 1.

26 Shalom H. Schwartz, «Basic Values: How They Motivate and Inhibit Prosocial Behavior» in: Mario Mikulincer/ Phillip R. Shaver (eds.), Prosocial Motives, Emotions, and Behavior: The Better Angels of our Nature (APA 2010).

27 SCHWARTZ analysed a total 25,863 value questionnaires completed by students and teachers in 20 countries. Shalom H. Schwartz, «Universals in the Content and Structure of Values: Theoretical Advances and Empirical Tests in 20 countries» Advances in Experimental Social Psychology, 1992, 25 1; Shalom H. Schwartz, «Are There Universal Aspects in the Structure and Content of Human Values?» Journal of Social Issues, 1994, 5019.

28 Shalom H. Schwartz, «Are There Universal Aspects in the Structure and Content of Human Values?» Journal of Social Issues, 1994, 50, 19, page 21.

29 Shalom H. Schwartz, «Are There Universal Aspects in the Structure and Content of Human Values?» Journal of Social Issues, 1994, 50, 19. 
[24] Decision-making within psychology is framed in the context of a choice, and FeATHER argues that all choices between alternatives, whether personal, policy or political, involve a decision between two or more competing values. ${ }^{30}$ An individual can affirm all of the values, but in reaching a decision between competing values, an individual will prioritise one or more values above others. For example, in the debate regarding detainment without trial, the competing values might be those of security and self-direction which encompasses liberty. ${ }^{31}$ In a binary value decision, the decision maker who supports detention is prioritising the values encompassed in security over those encompassed in self-direction. However, the role of values in decision-making is more complex than a simple decision between two alternatives. It requires a more nuanced balancing and prioritising of sets of competing values, which occurs at every level of decisionmaking. Values are activated at the system 1 level of decision-making, the instinctive response to the choice. This value-based response is affirmed, modified or rejected following deliberative reasoning. In a case, where deliberative reasoning does not provide a clear answer, the decision remains anchored in values.

[25] Value-based decisions making is evident in the judgments of the UK Supreme Court. ${ }^{32}$ In over $75 \%$ of all cases the UK Supreme Court reach a unanimous decision. In these cases, there is a legally «more correct» answer which can be identified through application of legitimate legal principles. However, in the minority of cases which divide judicial opinion, cases in which legal sources support two legitimate opposing outcomes, the decision reached was underpinned by the nuanced balancing of competing values. Many of these cases were those perceived by the court as the most important and raised issues on which society was divided. ${ }^{33}$ In every case there was a differential pattern of value expression, with those in the majority prioritising one value or a series of values above those prioritised by the minority. The systems-based psychology of decision-making suggests that in these uncertain decisions, where a judge exercises discretion, values play a role.

[26] Whereas all value priorities are vulnerable to deliberative reasoning, some «core» values are more consistently expressed. In the most uncertain cases, those which closely divide judicial opinion, value analysis of the UK Supreme Court demonstrated that Justices consistently reached decisions which aligned to a specific subset of values. Indeed, many would express these values whilst dissenting alone. This subset of values varied among individuals. It is this individual value difference which is evidence of value diversity and the different perspectives required for legitimate judicial decision-making.

[27] In many of these cases, the values which were prioritised aligned with those values associated with political ideology, but the values affirmed also reflect other facets of the judicial identity. Values thus provide a more nuanced reflection of the many factors that influence decision-making and judicial diversity than a single focus on political alignment.

30 Shalom H. Schwartz, «Value Priorities and Behaviour: Applying a Theory of Integrated Value Systems» in: Clive Seligman/James M. Olsen/Mark P. Zanna (eds.), Values: The Ontario Symposium, Vol. 8 (Erlbaum Psychology Press 1995).

31 This examples is chosen from the debates in the UK surrounding the Terrorism Act 2006 as amended by the Protection of Freedoms Act 2012.

32 For a detailed discussion of the role of values in judicial decision-making see Rachel CAHILL-O'CALLAGHAN, Values in the Supreme Court: Decisions, Division and Diversity, Hart Publishing, 2020.

33 Many of the cases which divide judicial opinion in the UK Supreme Court are those heard by an expanded panel. 


\section{The factors that influence judicial decision-making reflect values}

[28] Psychological studies have demonstrated that values underpin political ideologies and attitudes and the resultant value affirming behaviours. ${ }^{34}$ For example, Barnea and Schwartz (1998) demonstrated that individuals who espouse conservative ideology hold security and tradition in higher regard than those who support liberal ideologies. ${ }^{35}$ These values are commonly expressed in judgments which divide the Supreme Court and are reflected in the affirmation of national and personal security, and social and legal traditions. In legal decisions, these values were often in opposition to universalism. Universalism has the overarching motivation of understanding, tolerance and protection of the welfare of all people. These values oppositions were associated with $55 \%$ of division in the court. But in each of these cases where universalism was in opposition to tradition and security, other values were also evident. Indeed, it is notable that the differences in expression of values was not limited to the values associated with ideology.

[29] Some of the values expressed in division are also associated with role orientation, whether an individual is an activist or a restraintist. For example, SPINI and DoIse (1998) demonstrated an association between role orientation and values in students. ${ }^{36}$ Students who identified as activist prioritised values associated with self-direction (freedom and autonomy) and universalism, while restraintist students prioritised values associated with power and tradition. These are values which were also evident in the judgments of cases which divide judicial opinions.

[30] But these values do not simply underpin conscious factors that influence decision-making, they also provide an insight into the less conscious factors that may play a role. Values and moral reasoning are also intimately linked. ${ }^{37}$ Moral reasoning forms the bridge between our personal values and our behaviour or decisions at the abstract value level, moral reasoning links values with the emotions and perceptions of rightness or wrongness they engender. In this way, values underpin moral reasoning and serve to anchor the moral position.

[31] Personal values therefore offer a more refined and exact insight into the many factors that influence the judicial decision, both conscious and less conscious. Evidence from the UK Supreme Court demonstrates a consistent pattern of individual judicial decision-making associated with value priorities and variation of value priorities amongst the judiciary. As such, an appointments process which centred on values rather than the more limited political ideology would present a more comprehensive and nuanced reflection of the many facets of the individual which influence the final decision.

34 For example Gregory R. Maio and James M. Olson, Value-Attitude-Behaviour Relations: The Moderating Role of Attitude Functions, British Journal of Social Psychology, 1994, 33.3, 301-312; Scott G. Morgan/Elizabeth Mullen/Linda J. SKitKa, «When Values and Attributions Collide: Liberals' and Conservatives» Values Motivate Attributions for Alleged Misdeeds, Personality and Social Psychology Bulletin 2010, 36.9, 241-1254.

36 Dario Spini and Willem Doise, Organizing Principles of Involvement in Human Rights and their Social Anchoring in Value Priorities, European Journal of Social Psychology 1998, 28.4, 603-622.

37 James Weber, Exploring the Relationship between Personal Values and Moral Reasoning Human Relations , 1993, $19.1,435-463$. 


\section{Appointments and values}

[32] The assumption that political ideology is an appropriate indicator of judicial decision-making is fundamentally flawed. This narrow focus on one conscious position neglects the many other facets of the individual judicial personality that may influence the final outcome. Values offer a more reflective alternative criteria for selection. Although, as will be discussed later, no single factor alone is reflective of the complex nexus of external and intrinsic factors that influence a final decision, values do provide an insight into many more facets of the individual character than political ideology alone. Values influence our conceptions of justice and fairness, indeed, an individuals' morals, attitudes, ideology and role orientation are underpinned by the values that an individual holds to be important. An appointment system based on values would not only reflect the many ideological positions that are at the centre of a political appointment system, it would also provide a more accurate reflection of the many facets of the individuals making the decision.

[33] It is possible to reflect the values of a society on the Supreme Court bench. Value priorities are identified through psychometric testing and a modified psychometric assessment of population value priorities has been an element of the European Social Survey for many years. Drawing on this data, it is conceivable that value priorities of the population could be represented in the court, producing a court that reflects the societal values. This will provide a more nuanced form of democratic representation, not one reliant on self-declaration but one with a foundation in innate characteristics of the individual. Thus, an appointment system grounded in the psychometric assessment of values would achieve more effectively the ambitions of the political appointments process, providing a more inclusive and representative framework of selection. It would also remove many of the concerns associated with party influence which led to the appeals for a lottery system. But a court that truly represents the population may not be what is required. There are surely extremes that the court should not contemplate, views and value positions that would undermine fundamental democratic principles. For example, a court populated entirely with activist judges may unsettle the central tenet of the separation of powers. Thus, an appointments commission would have to make a decision on the characteristics of the judge that they seek and how the appropriate balance could be achieved between a representative and reflective judiciary and one which amplifies the central tenets of the judicial role.

[34] While selection based on values provides a more nuanced and richer indicator of the judicial character, like political ideology, values as a selection criteria alone cannot capture the complexity of human nature. A selection system based on psychometric testing of values will not accurately ensure that different value priorities and the diversity of views these reflect are effectively represented in judicial discussions. Appointment based on a single characteristic of the individual neglects the social context of judicial decision-making. Values, like so many other facets of our character, are susceptible to trade-off, where a decision maker will reach a decision which is in conflict with their personal values but achieves an alternative agenda. Within the context of judicial decisions, a judge who self identifies as consistently prioritising those values associated with conservation, tradition, conformity and security, may reach a decision that does not align with these values for a range of reasons, not least collegiality, consensus, support in another decision, legal certainty, or future benefits. Although core values are more resistant to trade off they are 
not immune. ${ }^{38}$ In any decision, the influence of values may be modified by a range of psychological responses to external and internal factors. The central ambition of democratic representation was the ambition to represent a diversity of views in the process of judicial reasoning and this diversity of decision-making cannot be achieved by a single factor alone.

[35] The selection based on a single factor also serves to limit the pool of eligible candidates. It requires the identification of a pool of individuals who prioritise the required values - a broader pool than those aligned with a political party - but similarly one which limits applicants and the potential for diversity. The use of a single criteria to limit the pool of selection, whether by political ideology or values, serves to reduce the diversity that the process seeks to achieve. If at the heart of the appointments process is a desire for diversity of view, which underpins legitimate decision-making, then diversity should not be determined by any single factor. It may be therefore that the appointments process requires a more radical reform than a more comprehensive indicator of judicial character. The discussion of change prompted by the «lottery» debate offers a real opportunity for a more fundamental change of focus. One that moves from exclusion to inclusion and affirms the importance of diversity in every form.

[36] This is not to say that values should not be an important element of the appointment process. The requirement of a diversity of values on the judicial bench, rather than a selection criteria which serves to exclude, should be used to advocate for and support inclusion. Our values are formed and informed by our life experiences. Value diversity on the bench and the benefits this would bring is a reflection of the many facets of varied life experiences. An appointments system which affirms value diversity is one that affirms human diversity in all forms. Value assessment and enhancing value diversity should be used to support inclusion and to encourage a wider pool of candidates with a range of life experiences into the selection process. This valuesbased system of appointment should recognise the importance of diversity beyond the traditional demographic identifiers of nationality, gender, ethnicity, political ideology and include the many other factors that influence our values such as class, legal experience and life experience. This system of appointment would encourage the widest range of value priorities and through this the democratic representation the Swiss Supreme Court appointments system seeks to achieve. A value-based appointments process recognises that no single indicator of judicial identity is an accurate reflection of a judicial decision. It recognises the complexity of human nature and humanity and the many factors that influence the final outcome. An appointments process that promotes these many facets of diversity will ensure that the widest range of value priorities are reflected in the Swiss Supreme Court and create a court that reflects the diversity of the demos it serves.

Dr. Rachel Cahill-O'Callaghan is a Reader in Law at Cardiff School of Law and Politics, Cardiff University, Wales. She holds a PhD in Law and a PhD in Science.

This article draws on themes developed in her monograph «Values in the Supreme Court: Decisions, Division and Diversity» Hart Publishing 2020 which was shortlisted for the Birks Prize in legal scholarship 2020.

38 Jonathon Baron and Mark Spranca, Protected Values, Organizational Behavior and Human Decision Processes, $1997,70.1,1-16$. 